\title{
Relationships between plant Viruses and their Aphid and Leafhopper vectors
}

\author{
par D. PETERS \\ State Agricultural University, Laboratory of Virology, \\ Binnenhaven 11, Wageningen, Pays-Bas
}

\begin{abstract}
Résumé
Le comportement des virus chez les pucerons et les cicadelles sera discuté. En général, on distingue trois types de transmissions virales. Ce sont: virus adhérant au stylet, virus circulant dans l'insecte et virus s'y multipliant.

Le premier type de transmission est effectué seulement par les pucerons. Ces virus sont acquis et transmis en quelques secondes ou minutes. L'essence de ce type de transmission semble être une adhérence du virus à la surface des stylets, puis son élution dans la ponction nutritive suivante.

Les autres virus de plantes peuvent être acquis par les pucerons et les cicadelles par les pièces buccales, accumulés dans l'organisme puis passés dans les tissus de l'insecte et introduits de nouveau dans les plantes par les pièces buccales de l'insecte. $\mathrm{Ce}$ mode de transmission demande un délai d'environ un jour (virus circulant) ou d'une semaine ou plus (virus se multipliant dans l'insecte).

La multiplication de certains virus, par exemple le virus de la tumeur de blessure, le virus du rabougrissement du riz, du nanisme jaune de la pomme de terre, chez leurs hôtes cicadelles, est connu depuis de nombreuses années. Récemment, il a été mis en évidence de façon certaine, la multiplication du virus des nervures jaunes du laiteron, un virus porté par les pucerons.

L'association du virus du rabougrissement du riz et du virus de la tumeur de blessure avec les tissus de leurs vecteurs est mise en évidence au microscope électronique. Ceci pourrait être mis
\end{abstract}


aussi en évidence par les techniques d'immunofluorescence pour le virus de la tumeur de blessure.

Le lieu initial de la multiplication du virus de la tumeur de blessure semble être le conduit intestinal. L'infection de l'intestin a lieu 4 jours après la contamination, tandis que les autres tissus ne sont atteints que 11 jours après.

Les virus de la tumeur de blessure et du nanisme jaune de la pomme de terre sont inoculés avec succès aux cultures de cellules de la cicadelle Agallia constricta. Des cultures primaires de puceron Hyperomyzus lactucae sont inoculées avec succès avec le virus des nervures jaunes du laiteron.

La transmission des virus se multipliant dans l'insecte est caractérisée par:

1) une longue période d'incubation (une à deux semaines),

2) une augmentation du rendement en virus pendant la période d'incubation,

3) la fréquence de transmission indépendante et non proportionnelle à la longueur de la période d'acquisition.

La transmission des virus simplement circulant est caractérisée par:

1) la période d'incubation est de moins de un jour,

2) une diminution du rendement viral après lacquisition du virus,

3) le meilleur moment pour la transmission est très proche de l'acquisition,

4) l'acquisition répétée de nourriture favorise la transmission.

Il semble que l'un des virus (celui de l'enroulement de la pomme de terre) qui a une transmission caractéristique « des virus circulants », se multiplie, en fait, dans son vecteur. Des passages en séries avec d'autres virus «circulants » donnent des résultats négatifs. Il semble donc nécessaire que la multiplication du virus de l'enroulement de la pomme de terre soit confirmée par de nouveaux faits.

Comme nous en discuterons plus loin, la réplication, chez les vecteurs, des virus «qui se multiplient » est un facteur important alors qu'il n'en est rien, si elle existe, pour les virus « qui circulent ».

\section{Summary}

The behaviour of viruses in aphids and leafhoppers will be discussed. Usually three types of virus transmission are distinguished. They are: stylet-borne, circulative and propagative. 
The first group is only transmitted by aphids. These viruses are acquired and transmitted within a period of seconds or minutes. The essence of this type of transmission seems to be an adherence of the virus to the surface of the stylets and its elution in the subsequent feeding probe.

Other plant viruses are acquired by aphids and leafhoppers through their mouthparts, accumulate internally, then pass through the insect tissues, whereafter they are introduced into plants again via the mouthparts of the vector. This process requires a period of about a day for circulative and a week or more for propagative viruses.

Multiplication of certain viruses, e. g. wound tumor virus, rice dwarf virus, potato yellow dwarf, in their leafhoppers has been known for several years. Unequivocal evidence for the multiplication of sowthistle yellow vein virus, an aphid borne virus, has been given recently.

Association of rice dwarf virus and wound tumor virus with tissues of their vectors has been demonstrated by electron microscopy.

This could also be demonstrated with immunofluorescence techniques for wound tumor virus.

The initial site of multiplication of wound tumor virus seems to be the intestinal tract. Infection of the intestine took place 4 days after acquisition, whereas other tissues showed positive reactions 11 days after acquisition.

Wound tumor virus and potato yellow dwarf are successfully inoculated to cell cultures of the leafhopper Agallia constricta. Primary cultures of the aphid Hyperomyzus lactucae were successful inoculated with sowthistle yellow vein virus.

The characteristics of transmission of propagative viruses are :

1) a long incubation period (1-2 weeks),

2) an increase of the virus content during the incubation period,

3) the frequence of transmission is independert on or not proportional to the length of the acquisition period.

The characteristics of transmission of circulative viruses are:

1) an incubation period of about a day,

2) a decrease of the virus content after acquisition of the virus,

3) the maximum inoculation efficiency will be reached shortly after acquisition,

4) repeated acquisition feeding affect the transmission positively.

There is strong evidence for one of the viruses (potato leafroll virus), which has a transmission characteristic of circulative viruses that it multiplies in its vector. Transmission experiments in which other circulative viruses were subjected to serial passage, 
were unsuccessfull. Therefore, its seems necessary that the multiplication of potato leafroll virus has to be confirmed by additional evidence.

The hypothesis is launched that multiplication of propagative viruses in their vector is a prerequisite for their transmission whereas a possible multiplication of circulative viruses vectors is not or only of minor importance for their transmission.

The primary objectives of this presentation are to discuss different aspects of the behaviour of some plant viruses within their arthropod vectors. Although a large number of plant viruses are transmitted from infected to healthy plants by aphids and leafhoppers, others are transmitted by white flies, beeties, mealy bugs, thrips, mites, and even by non-arthropods as nematodes, fungi and pollen. This discussion, however, will be restricted to the relationships between viruses and their aphid and leafhopper vectors, since these are intrinsically more interesting and have been more extensively studied than other virus-vector relationships.

In the transmission of plant viruses two or three types of virus-vector relationships are usually recognized. One group of plant viruses, the stylet-borne viruses, are transmitted by aphids only. Aphids acquire these viruses by brief superficial probes on an infected source plant, and are then almost immediately able to transmit virus to healthy plants. The aphid inserts its stylets into the plant, the stylets become contaminated with virus, and in a subsequent test probe the stylets can inoculate a healthy plant. The distal few microns only of the stylets are involved as can be demonstrated by ultra violet irradiation studies. The whole process of acquisition and transmission occurs within seconds or minutes. The essence of this type of transmission seems to be an adherence of the virus to the surface of the stylets and its elution during the subsequent feeding probe. However, the occurrence of vector specificities indicates that the mechanism of transmission is not merely mechanical, but rather more complicated than a prick of a needle. Vector specificity, although a subject for much speculation, may be attributed to interactions of processes at present unknown occurring on the outside of the stylets (Bradley, 1963).

More complex biological relations exist between circulative and propagative viruses and their insect vectors. These viruses are ingested through the mouth parts (mostly from the phloem of the plant) then, in some way penetrate the intestinal wall and pass through the haemocoel of the insect to the salivary glands; when such insects feed on healthy plants virus is introduced into the plants with saliva excreted via the mouth parts. In those cases in which this passage is completed without detectable virus multiplication within the vector the kind of transmission will be designated circulative. If the passage includes multiplication the term propagative will be used as proposed by Huff (1931) and Black (1959).

The relations of the last group of viruses to their vector, possibly because of their greater intrinsic interest are much better understood than those of the circulative viruses. They have a reproductive cycle in their insect vectors as may be concluded from 
transovarial and serial passages of rice dwarf and wound tumor viruses. Fukushi (1939) demonstrated that rice dwarf virus from a single infective female could be passed through the eggs to six succeeding generations without replenishment from infected plants. Although he did not estimate the final dilution of the starting quantity of virus attained in his experiment, Black (1953) calculated that the minimum dilution in Fukushi's experiment was 1: 563,000, and assumed that the actual value was considerably higher.

Multiplication of wound tumor virus in its vector Agallia constricta Van Duzee was also demonstrated by serial passage tests (Black and Brakke, 1952). Virus from viruliferous leafhoppers was injected into virus-free leafhoppers. After some days the injected leafhoppers were then used as a source of virus for injecting a second lot of virus-free insects. This process was repeated until after seven passages the virus had been diluted to $10^{-18}$. Nevertheless, the inoculativity of the last injected group was as high as that of the original group. With these techniques the virus had been passaged from insect to insect until the final dilution undoubtedly exceeded the maximum infective dilution of the starting materiai. Therefore, it was concluded that these viruses multiplied within their vectors. This conclusion can now be supported by numerous other observations.

Thus, corroborative evidence has been obtained by studies on the distribution and localization of these viruses in the tissues of their vectors. The association of rice dwarf virus with various internal organs of the leafhopper Nephotettix cincticeps Uhl. was demonstrated by electron microscopy. Clusters of virus particles ranging from small groups to large masses were found in the cells of intestinal epithelium, Malpighian tubules, blood, ovaries, salivary glands and fat bodies (Fukushi et al., 1960, Fukushi and Shikata, 1963). Similarly, Maramorosch and his co-workers (Shikata et al., 1965 ) showed that wound tumor virus was localized in various tissues of viruliferous leafhoppers. Only few scattered virus particles were found in one or two lobes of salivary glands. This finding is in contrast with findings made with the very efficient vector of rice dwarf virus, in which the lobes of the salivary glands contain large masses of virus particles.

Sinha and Black (1963) were able to detect viral antigens in the organs of viruliferous vectors by immuno-fluorescent techniques. By this method virus was detected in the brain, intestine, Malpighian tubules, salivary glands, mycetomes and the female reproductive organs. The testes, vesicular seminalis and accessory glands of the male reproductive organs did not show a positive reaction.

Using the same technique the sequence of infection sites in leafhoppers after ingestion of wound tumor virus was determined by Sinha (1965). Leafhoppers were given a one-day acquisition feed, then at various intervals internal organs were dissected and stained with fluorescein isothiocyanate-coupled antibodies.

Four and seven days after the start of the acquisition feed virus antigens could be detected only in the filter chamber of the intestine. After fourteen days positive reactions were detected in the fat body, brain, Malpighian tubules and the haemolymph and on the seventeenth day, the salivary glands were also shown to be invaded These 
results show that the intestine is the initial site of virus multiplication and that as the incubation period progresses, the virus gradually spreads to other organs.

A recent advance of greatest importance in the study of the virus-vector relations has been the establishment by Chiu and Black (1967) of cell lines of the vector (Agallia constricta) of wound tumor and potato yellow dwarf viruses. Black and his co-workers (Chiu et al., 1966; Chiu and Black, 1969 ; Chiu et al., in preparation) inoculated cell cultures with wound tumor and potato yellow dwarf viruses and subsequently, infected cells were detected by immuno-fluorescence techniques. Their results show that a quantitative method can be developed to assay the infectivity of these viruses. This may be expected for sowthistle yellow vein virus which can also be inoculated to primary cell cultures of ovarian and embryonic tissues from its aphid vector Hyperomyzus lactucae L. (Peters and Black, 1969). In these latter studies infected cells were first found 37 hours after inoculation ; the maximum number of infected cells was reached 12 hours later when about 1500 infected cells could be counted in a single culture.

When cells were infected with wound tumor virus brillant positive fluorescent spots occurred in the cytoplasma. By contrast, in cells infected with potato yellow dwarf and sowthistle yellow vein viruses, fluorescence occurs within the nuclei. These observations are in agreement with the distribution of these viruses in the cells of viruliferous vectors as observed by electron microscopy. Thus, wound tumor and rice dwarf viruses were found only in the cytoplasm (Shikata et al., 1965 ; Fukushi and Shikata, 1963) whereas the virions of potato yellow dwarf and sowthistle yellow vein viruses were found mainly in the nuclei and perinuclear spaces (MacLeod et al., 1966; Richardson and Sylvester, 1968).

The final type of relationship to be discussed is the group of so-called circulative viruses. After acquisition these viruses circulate in the vector and persist for a long time, even in some cases for its whole life span. Injection techniques have demonstrated that these viruses also occur in the haemolymph (Mueller and Rochow, 1961 ; Stegwee and Ponsen, 1958), and this is consistent with the retention of these viruses through moult. Virions of pea enation mosaic virus were observed by Shikata et al. (1966) in ultra thin sections of the fat body of viruliferous aphids. The particles were found either only in small numbers in tubular structures or loosely scattered in the cell cytoplasm. Potato leafroll virus has not yet been found in aphid vectors although tremendous efforts to do so have been made by Moericke (1963). Nevertheless, there is evidence that this multiplies in its vector. Stegwee and Ponsen (1958) carried out a serial transmission of this virus by injecting haemolymph from viruliferous aphids into a number of known virus-free aphids. These aphids were placed on healthy Chinese cabbage plants for seven days and their haemolymph was then injected into virus-free aphids. This process was repeated 15 times. At each passage the presence of leafroll virus in the injected aphids was demonstrated by feeding them on test plants (Physalis floridana Rydb.). It is calculated that if multiplication had not occurred, the virus would have been diluted to $10^{-21}$ by the 15 th passage, while the actual dilution end point of virus in haemolymph was estimated to be as high as $10^{-4}$. These results 
strongly support the view that potato leafroll virus multiplies in its vectors. Notwithstanding this evidence, there is still some uncertainty about this among plant virologists, presumably because results have not yet been confirmed by other independent observations. Moreover, serial passages of circulative viruses like beet curly top virus (Maramorosch, quoted by Black, 1959), barley yellow dwarf virus (Paliwal and Sinha, 1970) and pea enation mosaic virus (Sylvester and Richardson, 1966 b) have not been demonstrated, in spite of successful transmission of these viruses to their vectors by injection. In the light of these considerations it seems desirable that multiplication of potato leafroll virus should be confirmed by additional evidence.

Several other findings in the transmission and behaviour of circulative viruses have been interpreted as support for lack of multiplication. A gradual and progressive decrease of virus in viruliferous vectors after an acquisition feeding period may be the most significant observation. Harrison (1958) fed Myzus persicae Sulz. for 24 or 48 hours on potato leafroll-infected plants. After this feeding he divided the insects into three equal groups. One group was tested immediately for infectivity or virus content. The second group was placed for 24 or 48 hours on an immune plant, and the third group was similarly treated for 48 or 96 hours ; their virus contents was measured by injecting samples of macerates into virus-free aphids. The results showed that aphids just ending the acquisition feeding period carried a detectable amount of virus, whereas the macerates of the other groups of aphids did not. Evidently, the virus charge rapidly falls below a detectable concentration by subsequent feeding on immune hosts. This can be explained by a removal of virus from the intestinal tract along with excretion of sap ingested from the immune plant. Notwithstanding this exhaustion of virus the aphid remains infective for its whole lifetime. To infect a plant the virus load of an aphid may be rather small. By studying the relation of beet curly top virus in Circulifer tenellus, Bennett and Wallace (1938) also demonstrated that the decrease in virus content of viruliferous leafhoppers was more rapid than the decrease in inoculation efficiency. Both observations were interpreted as lack of multiplication of these viruses in aphids and leafhoppers.

Another significant observation may be that the inoculation efficiency is roughly proportional to the length of the acquisition feeding period. The minimum acquisition threshold period is approximately 5 to 10 minutes for these viruses, but the inoculation efficiency increases considerably by the extending of the acquisition feeding period into the range of hours or days. This was demonstrated when one day old nymphs of the aphid $M$. persicae were allowed to feed for various periods on potato leafroll-infected plants (Peters and Asjes, unpublished). After confining these aphids for four days on cabbage plants the aphids were tested for their inoculativity in five successive daily inoculation feedings on test plants. When the average percentage of infected plants is plotted against the acquisition feeding time, it appears that the inoculation efficiency increases proportionally with the length of the acquisition feeding. That the length of the acquisition determines the transmission rate could also be demonstrated by repeated acquisition feedings. The percentage of leafhoppers able to transmit beet curly top virus decreases with the age of acquisition. Nevertheless, the ability could be increased 
by a second acquisition feeding (Freitag, 1936). Recharging of the pea aphid Acyrthosiphon pisum with pea enation mosaic virus (Sylvester and Richardson, $1966 a$ ) was less successful since it did hardly affect the rate of tranmission. This may be due to the short life span of aphids, but also to the steady decrease of feeding activity which shows a similar decline as that of the inoculation efficiency (Sylvester, 1967).

The existence of an incubation time is often used as an argument in favour of multiplication. Although this may be correct for viruses with a long incubation time, it is uncertain whether it will be true for those with short incubation times. Acquisition and inoculation of circulative viruses and also of potato leafroll virus can be accomplished within a day for an individual vector. The incubation time reached then such low minimum values that it remains to be seen whether multiplication has also occurred within this period.

The relation of the length of the acquisition period to the inoculation efficiency, the drop in virus content of the vector after acquisition, the increase of inoculation efficiency after recharging, and the short incubation times found are phenomena which do not support the view that these viruses are multiplied in their vectors. These phenomena are characteristic for the so-called circulative viruses.

Although we have not discussed in detail the transmission properties of the propagative viruses, we can summarize them briefly. The transmission is characterized by a long incubation period (1-2 weeks), the virus content increases during the incubation period, and the frequency of transmission is independent of or not proportional to the length of the acquisition period. All these properties can be explained by multiplication of the viruses to be transmitted.

When these transmission properties are compared with those of the circulative viruses it is obvious that beyond the question whether plant viruses multiply in their vectors, two groups of viruses with distinct biological cycles can be constituted. The long incubation period of propagative viruses and the coincidence of the detection of viral antigens in salivary glands of wound tumor-infected vectors with the end of the incubation period indicate that these viruses must be multiplied prior to their transmission. This seems not to be the case for circulative viruses since they can be transmitted after short incubation periods. Such short periods are indicative for the absence of multiplication and so are the other transmission characteristics of this group of viruses as discussed previously.

\section{Bibliography}

Bennett (C. W.) and Wallace (H. E.), 1938. - Relation of the curly top virus to the vector, Eutettix tenullus. J. of Agric. Res., 56, 31-51.

BLACK (L. M.), 1959. - Biological cycles of plant viruses in insect vectors. In : \& The Viruses $\gg, 2,157-185$, Academic Press, New York.

-, 1953. - Viruses that reproduce in plants and insects. Ann. N.Y. Acad. Sci., 56, 398-413. 
- and BraKKe (M. K.), 1952. - Multiplication of wound tumor virus in an insect vector. Phytopathology, 42, 269-273.

Bradley (R. H. E.), 1963. - Aphid transmission of stylet-borne viruses. In: « Plant Virology » (M. K. Corbett and H. D. Sisler, eds.), pp. 148-174, Univ. of Florida Press, Gainesville.

CHIU (R. J.) and BLACK (L. M.), 1967. - Monolayer cultures of insect lines and their inoculation with a plant virus. Nature, 215, 1076-1078.

-,,- 1969 . - Assay of wound tumor virus by the fluorescent cell counting technique. Virology, 37, 667-677.

-, REDDY (D. V. R.) and BLACK (L. M.), 1966. - Inoculation and infection of leafhopper tissue cultures with a plant virus. Virology, 30, 562-566.

Freitag (J. H.), 1936. - Negative evidence on multiplication of curly top virus in the beet leafhopper Eutettix tenellus. Hilgardia, 10, 305-342.

FUKUSHI (T.), 1939. - Retention of virus by its insect vector through several generations. Proc. Imp. Acad. (Japan), 15, 142-145.

Fukushi (T.) and Shikata (E.), 1963. - Localization of rice dwarf virus in its insect vector. Virology, 21, 503-505.

Fukushi (T.), Shikata (E.), Kimura (I.) and Nemoto (M.), 1960. - Electron microscopy studies on the rice dwarf virus. Proc. Japan Acad., 36, 352-357.

HARRISON (B. D.), 1958. - Studies on the behaviour of potato leafroll and other viruses in the body of their aphid vector Myzus persicae (Sulz.). Virology, 6, 265-277.

HUFF (C. G.), 1931. - A proposed classification of disease transmissions by arthropods. Science, 74.

MOERICKe (V.), 1963. - Ueber «Virusartige Körper» in Organen von Myzus persicae (Sulz.). Z. Pflanzenkrankh., 70, 464-470.

Mueller (W. C.) and Rochow (W. F.), 1961. - An aphid injection method for the transmission of barley yellow dwarf virus. Virology, 14, 253-258.

Peters (D.) and Black (L. M.), 1970. - Infection of primary cultures of aphid cells with a plant virus. Virology, 40, 847-853.

Richardson (J.) and Sylvester (E. S.), 1968. - Further evidence of multiplication of sowthistle yellow vein virus in its aphid vector Hyperomyzus lactucae. Virology, 35, 347-355.

SinHA (R. C.), 1965. - Sequential infection and distribution of wound tumor virus in the internal organs of a vector after ingestion of virus. Virology, 26, 673-686.

- and BLACK (L. M.), 1963. - Wound tumor virus antigens in the internal organs of an insect vector. Virology, 21, 183-187.

Shikata (E.), Maramorosch (K.) and Granados (R. R.), 1966. - Electron microscopy of pea enation mosaic virus in plants and aphid vectors. Virology, 29, 426-436.

Stegwee (D.) and Ponsen (M. B.), 1958. - Multiplication of potato leafroll virus in the aphid Myzus persicae (Sulz.). Entomol. Exptl. Appl, 1, 291-300.

Sylvester (E.S.), 1967. - Retention of inoculativity in the transmission of pea enation mosaic virus by pea aphids as associated with virus isolates, aphid reproduction and excretion. Virology, 32, 524-531. 
— and RICHARDSON (J.), 1966 a. — « Recharging 》 pea aphids with pea enation mosaic virus. Virology, 30, 592-597.

-, $1966 b$. - Some effects of temperature on the transmission of pea enation mosaic virus and on the biology of the pea aphid vector. J. Econ. Entomol., 59, 255-261.

Paliwal (Y.C.) and Sinha (R.C.), 1970. - On the mechanism of persistence and distribution of barley yellow dwarf virus in an aphid vector. Virology, 42, 668-680 